\title{
Adoption of Recommended Practices of Rice Agri-Business
}

\section{S Ghimire ${ }^{1 *}$ and S Parajuli}

${ }^{1}$ Department of Agricultural Economics and Agribusiness Management, Agriculture and Forestry University, Rampur, Chitwan, Nepal ${ }^{2}$ Department of Agricultural Extension and Rural Sociology, Agriculture and Forestry University, Rampur, Chitwan, Nepal

*Corresponding Author: S Ghimire, Department of Agricultural Economics and Agribusiness Management, Agriculture and Forestry University, Rampur, Chitwan, Nepal.

Received: June 03, 2019; Published: July 11, 2019

DOI: $10.31080 /$ ASAG.2019.03.0569

\begin{abstract}
The study was conducted in June 2018 to know the level of adoption of recommended technology of rice agribusiness sector by the farmers in Lamjung district. In this district Rainas and Sundarbazar rice growing pocket areas were purposively selected for the study. The main purpose of the study was to examine the level of adoption of improved farm practices on rice cultivation. From each pocket area 50 rice growing farmers were randomly selected through lottery method. Thus the sample size was 100 . Survey method was used to collect primary information through semi structured interview schedule. Pre-tested and revised questionnaire was used to collect information. The data were processed and analyzed by using descriptive and inferential statistics through Ms excel and SPSS. The analysis showed that majority of the respondents were male, majority of them were in middle age group, literate, had medium family size and medium level of income. The average land holding size was 0.68 hectare. Majority of the respondents were affiliated to the farmer's group and majority of them had not received training on rice cultivation. Major source of knowledge used by farmers for improved technology of rice cultivation was neighbors, friends, JT (Junior Technicians)/JTA (Junior Technician Assistant), radio and television etc. The level of adoption of improved rice technology by farmers was moderate to high level. The average level of technology adoption was 74.16 percent. Correlation analysis showed that level of education and extension contact had positive and significant relationship with the level of education and extension contributed 21.3 percent variation to the level of adoption. Unavailability of quality seeds, insecticides, and chemical fertilizers, problems of storage, marketing/price, agricultural loan and irrigation were the major constraints faced by the farmers on rice cultivation.
\end{abstract}

Keywords: Adoption Level; Explanatory Variables; Correlation; Multivariate Regression

\section{Introduction}

Rice (Oryza sativa) is the staple food of Nepal and a mainstay for the rural population and food security. It is cultivated from vedic era in Nepal. Geographically, rice is grown in all agro-ecological zones ranging from terai (100-300 masl), valleys and foot hills (300-1000 masl) to the high mountains (1500-2600 masl). Double cropping of rice is grown at around (900 masl) and rice reaches its altitudinal limits at 2600 masl $[1,2]$. Few countries have such a diversity of rice growing environment as Nepal. Nepal has the highest place where rice is grown in the world.

The crop plays a significant role in Nepalese economy contributing 23 percent of the AGDP (Agriculture Gross Domestic Product) in the agricultural area. It also meets more than 50 percent of the total calories requirement of the Nepalese people. The main diet of Nepalese is also rice. It supplies 38.5 percent of the dietary energy, 29.4 percent of dietary protein per capita, 7.2 percent dietary fat in Nepal [3].

Rice is not only the staple food for Nepalese people but also an important source of feed to livestock during the fodder deficit period and it is also a major employer and source of income for the poor. The crop has three important by products; rice straw, husk, and bran, which contribute substantially to agriculture and agrobased industries in Nepal. Rice straw meets 32.37 percent of total agriculture markets required for 8.6 million livestock unit [4].

Preliminary estimate indicates that rice was grown in 1.55 million ha producing 5.45 million mt paddy, with a productivity of 3.85 mt per hectare during 2013/14. Normal (main season) rice occu- 
pies a major proportion of the total rice area in Nepal i.e. 48 percent of the total rice area under cereal crops is covered by rice [5].

As rice is grown under diverse soil and climatic condition, the growth in rice production is low (grain yield 2.0 percent per annum) compared to rate of population growth (2.2 percent per annum). Thus, Nepal has become a net rice importing country which imports worth of 75 corers rupees from India [6].

Food insecurity and poverty are the major problems of the country. Productivity of major cereals and cash crops had declined since 1980 [7]. Low productivity, very low rate of technology adoption and its limited impact on production have confused policy makers, planners and agriculturists [8].

Several technologies have been generated by research to solve the problems of rice growers but not all have been adopted by the farmers. Some farmers are very quick to adopt improved innovations and put them into action but some farmer do not adopt innovations because the adoption of improved technologies varies from farmer to farmer according to their knowledge, ineffective communication methods, socio-economic factors, extension contact and availabilities of resources [9]. Technologies would have no value if farmers are not adopting and their socio economic status is not being improved. Adoption is a process by which a particular farmer is exposed to, considers and finally rejects or practices a particular innovation [10].

A major difference between the diffusion and adoption process is that diffusion occurs among persons while adoption is an individual matter [11]. The variables such as level of education, opinion leadership status, organizational membership, extension contact, group size, formalization, satisfaction, sources of information and member's attitude were found to be relatively positive with the level of participation [12].

Since the inception of rice research program in 1972, a number of rice technologies/varieties have been developed but the status of adoption of these technologies have not been studied in the hilly area of Nepal. Rice is the main crop of Lamjung district in terms of land coverage and production. Lamjung, a hilly district lies in Gandaki Province of Nepal. The total area and production of rice is 16545 ha and production is $42213 \mathrm{mt}$. respectively. The productivity of rice is $3.07 \mathrm{mt}$ per ha [13].

There is huge yield gap between the research farm and in farmer's field. To reduce the gap, it is needed to find the main reasons of lower yield and low level of technology adoption. Limited study has been conducted in this sector. The findings would be useful to the farmers, extension workers, researchers, and policy makers to develop effective rice development program.

\section{Research Methodology}

Study area and sample size

This study was carried out in Lamjung district of Nepal. Among the different rice growing pocket areas; two pocket areas (Rainas and Sundarbazar) were purposively selected as study sites. The list of farmers was used as a sampling frame to select the respondents. A total of 100 farmers 50 from each pocket were randomly selected for the study. Primary data were collected through personal interview using semi-structured and pre-tested questionnaires. Secondary information was obtained through reviewing different publications of different institutions (DADO Lamjung, NGOs and INGOs), informal group discussions, participatory observations and key-informant survey.

Field survey was conducted in July, 2018. The collected data was analyzed using both descriptive and inferential statistics. The descriptive statistics was used to describe the respondent's socioeconomic characters such as age, sex, level of education, farm size, family size, annual income, organizational membership, extension contact and training. These were considered as the independent variables. Correlation coefficient was used to measure the relationship between dependent and independent variables and multiple regression model was used for determining the effect and contribution of variables. The collected information were first tabulated, coded and entered in to the computer. Final analysis was done by using computer software packages: Microsoft Excel and Statistical Package for Social Sciences (SPSS).

\section{Conceptual framework}

Variables of the study
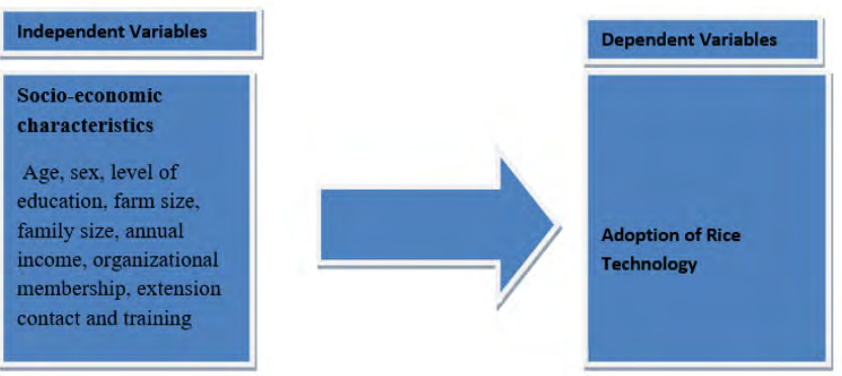

Figure 1: Conceptual framework showing factors affecting technology adoption and rice technology adoption.

\section{Variables of the study}

Eight important cultivation practices of rice were selected for the study, which was developed by NRRP (National Rice Research 
Program), Hardinath, Janakpur. These practices were use of improved varieties, seed rate, age of seedlings, number of seedlings per hill, recommended dose of manures and fertilizers, weeding, disease and pest management measure and post harvest technology. Out of 50 score, researcher asked to the extension specialist of DADO, Lamjung to assign the score based on the importance of the rice cultivation. Appropriate scores were assigned by them for each practice. Average score was calculated from the score assigned by the extension specialist as shown in the Table 1.

\begin{tabular}{|l|c|c|}
\hline S.N & Improved practices & Average score \\
\hline 1 & Improved varieties & 10.5 \\
\hline 2 & Irrigation & 8.0 \\
\hline 3 & Manure and fertilizer & 7.4 \\
\hline 4 & Seed rate & 5.5 \\
\hline 5 & Weeding & 4.2 \\
\hline 6 & Disease and insect-pest & 4.0 \\
\hline 7 & management & 3.6 \\
\hline 8 & Age of seedlings & 3.1 \\
\hline 9 & Pumber of seedlings per hill & 2.3 \\
\hline 10 & Host harvest technology & 1.4 \\
\hline & Total & \\
\hline
\end{tabular}

Table 1: Average score assigned by agriculture extension specialists.

\section{Level of technology adoption}

The level of adoption of improved rice technology was determined by the following formula [14]. Unit was expressed in percentage.

Level of adoption $(\%)=\frac{1}{n}\left\{\frac{X 1 * 100}{A 0}+\frac{X 2 * 100}{S r 0}+\cdots+\frac{X 8 * 100}{\text { Pht0 }}\right\}$

Where,

$\mathrm{X}_{1}=$ Area under high yielding varieties

$\mathrm{X}_{2}=$ Seed rate used for hectare

$\mathrm{X}_{3}=$ Age of seedlings used for transplanting

$X_{4}=$ Number of seedlings per hill

$\mathrm{X}_{5}=$ Fertilizer used per hectare

$\mathrm{X} 6=$ Number of weeding practiced

$\mathrm{X}_{7}=$ Pest management method practiced by the farmers

$\mathrm{X}_{8}=$ Post harvest technology practice by the farmers

$A_{0}=$ Total crop area of enumeration unit

$\mathrm{Sr}_{0}=$ Recommended dose of seed rate per hectare
$\mathrm{Ag}_{0}=$ Recommended age of seedlings

$\mathrm{Ns}_{0}=$ Recommended number of seedlings per hill

$\mathrm{F}_{0}=$ Recommended dose of fertilizer

$\mathrm{Wd}_{0}=$ Recommended number of weedings

$\mathrm{Pm}_{0}=$ Recommended method of pest management

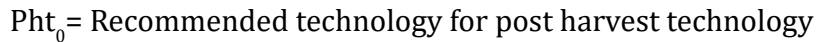

\section{Results and Discussion}

Socio-economic characteristics of the respondents Sex

From the study it was found that majority of respondents were male ( 57 percent) and female (43 percent). Male respondents were found higher than female respondents indicating that in Nepalese society, women are busy in daily household chores and they are less exposed to the society than man.

\begin{tabular}{|l|c|c|c|}
\hline \multirow{2}{*}{ Sex } & \multicolumn{2}{|c|}{ Pocket area } & \multirow{2}{*}{$\begin{array}{c}\text { Total } \\
\mathbf{n = 1 0 0}\end{array}$} \\
\cline { 2 - 3 } & $\begin{array}{c}\text { Rainas } \\
\mathbf{n = 5 0}\end{array}$ & $\begin{array}{c}\text { Sundarbazar } \\
\mathbf{n = 5 0}\end{array}$ & \\
\hline Male & $31(62.0)$ & $26(52.0)$ & $57(57.0)$ \\
\hline Female & $19(38.0)$ & $24(48.0)$ & $43(43.0)$ \\
\hline
\end{tabular}

Table 2: Distribution of sex of respondents.

Figures in the parenthesis indicate percentage

Age

The study shows that majority of respondents (67 percent) were under 32-57 years of age followed by 14 percent less than 32 years age and 19 percent above 57 years of age. The average age of the respondents of the study area was 44.91 years while the average age of people of district is 64.51 years [15].

\begin{tabular}{|c|c|c|c|}
\hline \multirow{2}{*}{$\begin{array}{c}\text { Age } \\
\text { categories }\end{array}$} & \multicolumn{2}{|r|}{ Pocket Area } & \multirow{2}{*}{$\begin{array}{c}\text { Total } \\
\mathbf{n}=100\end{array}$} \\
\hline & $\begin{array}{c}\text { Rainas } \\
\mathbf{n}=\mathbf{5 0}\end{array}$ & $\begin{array}{c}\text { Sundarbazar } \\
n=50\end{array}$ & \\
\hline$<32$ years & $9(18.0)$ & $5(10.0)$ & $20(20.0)$ \\
\hline $32-57$ years & $33(66.0)$ & $34(68.0)$ & 67 (67.0) \\
\hline$>57$ years & $8(16.0)$ & $11(22.0)$ & 19 (19.0) \\
\hline Mean & - & - & 44.91 \\
\hline $\begin{array}{l}\text { Standard } \\
\text { Deviation }\end{array}$ & - & - & 12.44 \\
\hline Range & - & - & $21-74$ \\
\hline
\end{tabular}

Table 3: Distribution of age of respondents.

Figures in the parenthesis indicate percentage 


\section{Caste and ethnicity}

From the study it was found that the main castes and ethnic groups of the study area were Brahmin (58 percent) followed by Janajati (28 percent), Chhetri (7 percent), Dalit (6 percent) and others (1 percent).

\begin{tabular}{|l|c|c|c|}
\hline \multirow{2}{*}{ Caste } & \multicolumn{2}{|c|}{ Pocket area } & \multirow{2}{*}{ Total } \\
\cline { 2 - 3 } & $\begin{array}{c}\text { Rainas } \\
\mathbf{n = 5 0}\end{array}$ & $\begin{array}{c}\text { Sundarbazar } \\
\mathbf{n = 5 0}\end{array}$ & $\mathbf{n = 1 0 0}$ \\
\hline Brahmin & $29(58.0)$ & $29(58.0)$ & $58(58.0)$ \\
\hline Chhetri & $4(8.0)$ & $3(6.0)$ & $7(7.0)$ \\
\hline Janajati & $12(24.0)$ & $16(32.0)$ & $28(28.0)$ \\
\hline Dalit & $4(8.0)$ & $2(4.0)$ & $6(6.0)$ \\
\hline Other & $1(2.0)$ & - & $1(1.0)$ \\
\hline
\end{tabular}

Table 4: Distribution of caste and ethnicity of the respondents.

Figures in the parenthesis indicate percentage

\section{Religion}

Three types of religion were found in the study area. Hindu (88 percent) was found dominant followed by Buddhist (11 percent) and Muslim (1 percent) respectively.

\begin{tabular}{|l|c|c|c|}
\hline \multirow{2}{*}{ Religion } & \multicolumn{2}{|c|}{ Pocket area } & \multirow{2}{*}{ Total } \\
\cline { 2 - 3 } & $\begin{array}{c}\text { Rainas } \\
\mathbf{n = 5 0}\end{array}$ & $\begin{array}{c}\text { Sundarbazar } \\
\mathbf{n = 5 0}\end{array}$ & \\
\hline Hindu & $46(92.0)$ & $42(84.0)$ & $88(88.0)$ \\
\hline Buddhist & $3(6.0)$ & $8(16.0)$ & $11(11.0)$ \\
\hline Muslim & $1(2.0)$ & - & $1(1.0)$ \\
\hline
\end{tabular}

Table 5: Distribution of religion of respondents

Figures in the parenthesis indicate percentage

Family size

The majority of the families were fallen in the medium size family (64 percent) followed by small size family (27 percent) and large size family ( 9 percent) as shown in the Table 6.

\section{Education level}

From the study it was found that, majority of the respondents were found literate (53 percent) followed by high school/SLC (23 percent), illiterate (13 percent) and intermediate level (11 percent) respectively.

\section{Distribution of family income}

Study shows that, all of the respondents (100 percent) had agriculture farming as the primary source of income. The second major

\begin{tabular}{|c|c|c|c|}
\hline \multirow[b]{2}{*}{ Family size } & \multicolumn{2}{|c|}{ Pocket area } & \multirow{2}{*}{$\begin{array}{c}\text { Total } \\
\mathbf{n}=100\end{array}$} \\
\hline & $\begin{array}{c}\text { Rainas } \\
n=50\end{array}$ & $\begin{array}{c}\text { Sundarbazar } \\
n=50\end{array}$ & \\
\hline Small $(<4)$ & $14(28.0)$ & $13(26.0)$ & $27(27.0)$ \\
\hline $\begin{array}{l}\text { Medium ( } 4 \\
\text { to 9) }\end{array}$ & $33(66.0)$ & $31(62.0)$ & $64(64.0)$ \\
\hline Large (>9) & $36(72.0)$ & $6(12.0)$ & $9(9.0)$ \\
\hline Mean & 5.86 & 6.42 & 6.14 \\
\hline $\begin{array}{l}\text { Standard } \\
\text { deviation }\end{array}$ & 2.31 & 2.84 & 2.59 \\
\hline Range & 11 & 12 & 14 \\
\hline
\end{tabular}

Table 6: Distribution of family size of respondents.

Figures in the parenthesis indicate percentage

\begin{tabular}{|l|l|l|l|}
\hline \multirow{2}{*}{$\begin{array}{c}\text { Level of } \\
\text { education }\end{array}$} & \multicolumn{1}{|c|}{$\begin{array}{c}\text { Pocket area } \\
\text { Rainas } \\
\mathbf{n = 5 0}\end{array}$} & $\begin{array}{c}\text { Sundarbazar } \\
\mathbf{n = 5 0}\end{array}$ & $\begin{array}{c}\text { Total } \\
\mathbf{n = 1 0 0}\end{array}$ \\
\cline { 2 - 3 } Illiterate & $9(18.0)$ & $4(8.0)$ & $13(13.0)$ \\
\hline Literate & $22(44.0)$ & $31(62.0)$ & $53(53.0)$ \\
\hline $\begin{array}{l}\text { High school and } \\
\text { SLC }\end{array}$ & $17(34.0)$ & $6(12.0)$ & $23(23.0)$ \\
\hline Intermediate & $2(4.0)$ & $9(18.0)$ & $11(11.0)$ \\
\hline
\end{tabular}

Table 7: Distribution of education level of respondents.

Figures in the parenthesis indicate percentage

source of income was livestock (72 percent) followed by service (39 percent), poultry (26 percent), foreign job (16 percent), business (13 percent) and others (12 percent).

\begin{tabular}{|l|l|l|l|}
\hline \multirow{2}{*}{$\begin{array}{c}\text { Sources of } \\
\text { income }\end{array}$} & \multicolumn{1}{|c|}{\begin{tabular}{c} 
Pocket area \\
Rainas \\
\cline { 2 - 3 }
\end{tabular}} & $\begin{array}{c}\text { Sundarbazar } \\
\mathbf{n = 5 0}\end{array}$ & $\begin{array}{c}\text { Total } \\
\mathbf{n = 1 0 0}\end{array}$ \\
\hline Agriculture & $50(100.0)$ & $50(100.0)$ & $100(100.0)$ \\
\hline Service & $11(22.0)$ & $28(56.0)$ & $39(39.0)$ \\
\hline Business & $6(12.0)$ & $7(14.0)$ & $13(13.0)$ \\
\hline Livestock & $24(48.0)$ & $48(96.0)$ & $72(72.0)$ \\
\hline Poultry & $10(20.0)$ & $16(32.0)$ & $26(26.0)$ \\
\hline Foreign job & $11(12.0)$ & $5(10.0)$ & $16(16.0)$ \\
\hline Others & $3(6.0)$ & $9(18.0)$ & $12(12.0)$ \\
\hline
\end{tabular}

Table 8: Distribution of income sources of the respondents. Figures in the parenthesis indicate percentage 


\section{Distribution of landholding size}

From the findings, it was observed that majority of the respondents had medium size land holding. The average land holding size of study area was 0.68 hectare.

\begin{tabular}{|l|c|c|c|}
\hline \multirow{2}{*}{$\begin{array}{l}\text { Land holding } \\
\text { size (ha) }\end{array}$} & \multicolumn{2}{|c|}{ Pocket area } & \multirow{2}{*}{$\begin{array}{c}\text { Total } \\
\mathbf{n = 1 0 0}\end{array}$} \\
\cline { 2 - 3 } & $\begin{array}{c}\text { Rainas } \\
\mathbf{n = 5 0}\end{array}$ & $\begin{array}{c}\text { Sundarbazar } \\
\mathbf{n = 5 0}\end{array}$ & \\
\hline Small $(<0.5)$ & $22(44.0)$ & $23(46.0)$ & $45(45.0)$ \\
\hline $\begin{array}{l}\text { Medium }(0.5 \\
-1.0)\end{array}$ & $19(38.0)$ & $18(36.0)$ & $37(37.0)$ \\
\hline Large (>1.0) & $9(18.0)$ & $9(18.0)$ & $18(18.0)$ \\
\hline Mean & - & - & 0.68 \\
\hline $\begin{array}{l}\text { Standard } \\
\text { deviation }\end{array}$ & - & - & 0.65 \\
\hline Range & - & - & 4.25 \\
\hline
\end{tabular}

Table 9: Distribution of land holding size of respondents.

Figures in the parenthesis indicate percentage

\section{Description of extension related factors}

\section{Training pattern}

The study shows that, majority of the respondents ( 82 percent) had not received training and 18 percent respondents had received training on rice cultivation respectively. Majority of the farmers had not received training on rice cultivation which could not help the farmer for updating the knowledge and skill in farming operations.

\begin{tabular}{|c|c|c|c|}
\hline \multirow[b]{2}{*}{ Training } & \multicolumn{2}{|c|}{ Pocket area } & \multirow{2}{*}{$\begin{array}{c}\text { Total } \\
\mathrm{n}=100\end{array}$} \\
\hline & $\begin{array}{c}\text { Rainas } \\
\mathbf{n}=\mathbf{5 0}\end{array}$ & $\begin{array}{c}\text { Sundarbazar } \\
n=50\end{array}$ & \\
\hline $\begin{array}{l}\text { Training not } \\
\text { received }\end{array}$ & $12(24.0)$ & $6(12.0)$ & $18(18.0)$ \\
\hline $\begin{array}{l}\text { Training } \\
\text { received }\end{array}$ & $38(76.0)$ & $44(88.0)$ & $82(82.0)$ \\
\hline
\end{tabular}

Table 10: Training patterns of the respondents.

Figures in the parenthesis indicate percentage

\section{Frequency of extension contact}

Farmers visit to extension workers in different time intervals. Some farmers visit frequently, some farmers visit less frequently and some do not visit to the extension workers. 'Once a week' is the most important frequency of contact followed by once a month, fortnightly and once a year by the farmers visit to the extension workers respectively.

\begin{tabular}{|l|l|l|l|}
\hline Frequency of contact & Score & Index value & Rank \\
\hline Once a week & 76 & 0.19 & I \\
\hline Fortnightly & 18 & 0.04 & III \\
\hline Once a month & 70 & 0.17 & II \\
\hline Once a year & 10 & 0.02 & IV \\
\hline Never & 0 & 0 & V \\
\hline
\end{tabular}

Table 11: Frequency of extension contact of the respondents with extension worker.

Note: The score value for frequency of contact ranged from 4 to 0 , where; $4=$ once a week, $3=$ fortnightly, $2=$ once a month, $1=$ once a year and $0=$ never

\section{Cropping pattern}

There were rice dominated cropping patterns in the study area. Table 12 reveals that major cropping patterns of the study area were Rice-Wheat-Rice (40 percent), Rice-Fallow-Rice (29 percent), Rice-Vegetable-Rice (21 percent), Rice-Wheat-Maize (6 percent) and Rice-Vegetable-Maize (4 percent). Majority of the farmers have adopted two seasons rice based cropping patterns and the area was almost fully covered by the crops round the year. Thus, the cropping intensity of the study area was also high.

\begin{tabular}{|l|c|c|}
\hline \multicolumn{1}{|c|}{ Cropping pattern } & Frequency & Percentage Rank \\
\hline Rice - Wheat - Rice & 40 & I \\
\hline Rice - Fallow -Rice & 29 & II \\
\hline Rice - Vegetable-Rice & 21 & III \\
\hline Rice - Wheat- Maize & 6 & IV \\
\hline Rice- Vegetable- Maize & 4 & V \\
\hline
\end{tabular}

Table 12: Major cropping pattern of the study area

\section{Adoption of rice technology}

Coverage of improved varieties

In the study area, 38 percent of the respondents had covered $26-50 \%$ of the area by improved variety, 33 percent of respondents had covered $51-75 \%$ of the area by improved variety, 21 percent of respondents had covered $76-100 \%$ of the area by improved variety and 8 percent of the respondents had covered one-fourth of their own land by improved varieties.

\section{Seed rate}

Recommended seed rate of rice by research is $40-50 \mathrm{~kg}$ per hectare. The study shows that, the average seed rate used by the farmers of the study area was $60.16 \mathrm{~kg}$ per hectare. It indicates that the amount of seed used by the farmers for rice cultivation was more than recommendation. 


\begin{tabular}{|c|c|c|c|}
\hline \multirow{2}{*}{$\begin{array}{l}\text { Area covered by } \\
\text { improved variety }\end{array}$} & \multicolumn{2}{|c|}{ Pocket area } & \multirow{2}{*}{$\begin{array}{c}\text { Total } \\
\mathbf{n}=100\end{array}$} \\
\hline & $\begin{array}{c}\text { Rainas } \\
n=50\end{array}$ & $\begin{array}{c}\text { Sundarbazar } \\
n=50\end{array}$ & \\
\hline Up to $25 \%$ & $3(6.0)$ & $5(10.0)$ & $8(8.0)$ \\
\hline $26-50 \%$ & $21(42.0)$ & $17(34.0)$ & 38 (38.0) \\
\hline $51-75 \%$ & $14(28.0)$ & $19(38.0)$ & $33(33.0)$ \\
\hline $76-100 \%$ & $12(24.0)$ & $9(18.0)$ & $21(21.0)$ \\
\hline Mean & 60.94 & & \\
\hline Standard deviation & 32.07 & & \\
\hline
\end{tabular}

Age of seedlings

Recommended age of seedlings for transplanting is 21-28 days by research. The study shows that, average age of seedlings used by the respondents was as per the recommendation.

\section{Number of rice seedlings per hill}

The recommended number of rice seedlings per hill for transplanting is 2-3 by research. The average number of rice seedlings used by respondents was as per the recommendation.

Table 13: Area covered by improved varieties of rice.

Figures in the parenthesis indicate percentage

\begin{tabular}{|c|c|c|c|c|c|}
\hline \multicolumn{6}{|c|}{ Pocket area } \\
\hline \multicolumn{3}{|c|}{ Rainas $\mathbf{n}=\mathbf{5 0}$} & \multicolumn{3}{|c|}{ Sundarbazar $n=50$} \\
\hline Seed rate & Frequency & Percentage & Seed rate & Frequency & Percentage \\
\hline 10 & 1 & 2.00 & 20 & 5 & 10.0 \\
\hline 20 & 6 & 12.00 & 30 & 4 & 8.00 \\
\hline 30 & 5 & 10.00 & 40 & 7 & 14.00 \\
\hline 36 & 1 & 2.00 & 60 & 12 & 24.00 \\
\hline 40 & 6 & 12.00 & 70 & 3 & 6.00 \\
\hline 50 & 7 & 14.00 & 80 & 5 & 10.00 \\
\hline 60 & 12 & 24.00 & 90 & 2 & 4.00 \\
\hline 70 & 2 & 4.00 & 100 & 1 & 2.00 \\
\hline 80 & 10 & 20.00 & 120 & 10 & 20.00 \\
\hline & & & 140 & 1 & 2.00 \\
\hline Total & \multirow{2}{*}{\multicolumn{5}{|c|}{$\begin{array}{l}100 \\
60.16\end{array}$}} \\
\hline Mean & & & & & \\
\hline
\end{tabular}

Table 14: Amount of rice seed used by respondents (kg per hectare).

\begin{tabular}{|l|c|c|c|}
\hline \multirow{2}{*}{$\begin{array}{c}\text { Age of } \\
\text { seedlings }\end{array}$} & \multicolumn{2}{|c|}{ Pocket area } & \multirow{2}{*}{$\begin{array}{c}\text { Total } \\
\mathbf{n = 1 0 0}\end{array}$} \\
\cline { 2 - 3 } & $\begin{array}{c}\text { Rainas } \\
\mathbf{n = 5 0}\end{array}$ & $\begin{array}{c}\text { Sundarbazar } \\
\mathbf{n = 5 0}\end{array}$ & $9(9.0)$ \\
\hline 15-20 Days & $9(18.0)$ & - & $71(71.0)$ \\
\hline 21- 28 Days & $37(74.0)$ & $34(68.0)$ & $16(16.0)$ \\
\hline 29-35 Days & $4(8.0)$ & $12(24.0)$ & $4(4.0)$ \\
\hline Above 35 Days & - & $4(8.0)$ & - \\
\hline Mean & $21-28$ Days & - & - \\
\hline $\begin{array}{l}\text { Standard de- } \\
\text { viation }\end{array}$ & 0.68 & - & \\
\hline
\end{tabular}

Table 15: Age of rice seedlings by respondents (days).

Figures in the parenthesis indicate percentage

\begin{tabular}{|c|c|c|c|}
\hline \multirow{2}{*}{$\begin{array}{c}\text { No. of rice } \\
\text { seedlings/hill }\end{array}$} & \multicolumn{2}{|c|}{ Pocket area } & \multirow{2}{*}{$\begin{array}{c}\text { Total } \\
\mathbf{n}=100\end{array}$} \\
\hline & $\begin{array}{c}\text { Rainas } \\
\mathbf{n}=\mathbf{5 0}\end{array}$ & $\begin{array}{c}\text { Sundarbazar } \\
n=50\end{array}$ & \\
\hline Single & $2(4.0)$ & $5(10.0)$ & $7(7.0)$ \\
\hline $2-3$ & $29(58.0)$ & $31(62.0)$ & $60(60.0)$ \\
\hline $3-4$ & $1(4.0)$ & $2(4.0)$ & $3(3.0)$ \\
\hline $4-5$ & $18(36.0)$ & $12(24.0)$ & $30(3.0)$ \\
\hline Mean & $\begin{array}{l}2.31 \text { (2-3 } \\
\text { seedlings) }\end{array}$ & - & - \\
\hline $\begin{array}{l}\text { Standard } \\
\text { deviation }\end{array}$ & 0.7 & - & - \\
\hline
\end{tabular}

Table 16: Number of rice seedlings per hill used by the respondents

Figures in the parenthesis indicate percentage 
Amount of manures and chemical fertilizers

Recommended dose of fertilizers for rice cultivation is 100:30:30 NPK per hectare. Majority of respondents used low amount of chemical fertilizers below the recommendation. Out of total respondents, 59 percent, 67 percent, 21 percent and 21 percent of the respondents used one-fourth, half, three-fourth and full dose of recommended fertilizers respectively. Low adoption of chemical fertilizers was due to the lack of technical knowledge, unavailability of quality fertilizers during planting time and chemical fertilizers are expensive too. Majority of the respondents (80 percent) used Urea as top-dressing but the dose was very low than recommendation.

\begin{tabular}{|l|c|c|c|c|}
\hline \multirow{2}{*}{$\begin{array}{c}\text { Amount of } \\
\text { manures } \\
\begin{array}{c}\text { and } \\
\text { fertilizer }\end{array}\end{array}$} & $\begin{array}{c}\text { Nitrogen } \\
\mathbf{n = 8 3}\end{array}$ & $\begin{array}{c}\text { Phosphorus } \\
\mathbf{n = 6 1}\end{array}$ & $\begin{array}{c}\text { Potash } \\
\mathbf{n = 2 4}\end{array}$ & $\begin{array}{c}\text { Total } \\
\mathbf{n = 1 0 0}\end{array}$ \\
\cline { 2 - 5 } Up to 25\% & $46(46.0)$ & $7(7.0)$ & $6(6.0)$ & $59(59.0)$ \\
\hline $26-50 \%$ & $32(32.0)$ & $22(22.0)$ & $13(13.0)$ & $67(67.0)$ \\
\hline $51-75 \%$ & $4(4.0)$ & $16(16.0)$ & $1(1.0)$ & $21(21.0)$ \\
\hline $76-100 \%$ & $1(1.0)$ & $16(16.0)$ & $4(4.0)$ & $21(21.0)$ \\
\hline Mean & - & - & - & 42 \\
\hline $\begin{array}{l}\text { Standard } \\
\text { deviation }\end{array}$ & - & - & - & 24.46 \\
\hline Range & - & - & - & 46 \\
\hline
\end{tabular}

Table 17: Manures and fertilizers used by the respondents.

Figures in the parenthesis indicate percentage

\section{Insect pest and disease management}

From the study it was found that, Blast, Khaira, Bacterial leaf blight, were found major diseases. Likewise, Stem borer, Rice gundhi bug, Army worm were major insect-pests. The study shows that, 49 percent respondents adopted insect-pests and diseases management practices and 51 percent respondents had not adopted such measures. There was less infestation because the study area was located in hilly region and the climate is moderate i.e. subtropical.

\section{Post harvest technology}

The study shows that out of total respondents, 59 percent respondents used two practices i.e. cleaning and drying, 22 percent respondents used only one practice i.e. cleaning and 19 percent responded used three practices i.e. cleaning, drying and safe storage. No respondent was found who had not adopted any practice.

\begin{tabular}{|c|c|c|c|}
\hline \multirow{2}{*}{$\begin{array}{l}\text { Insect- pests } \\
\text { management }\end{array}$} & \multicolumn{2}{|c|}{ Pocket area } & \multirow{2}{*}{$\begin{array}{c}\text { Total } \\
\mathbf{n}=100\end{array}$} \\
\hline & $\begin{array}{c}\text { Rainas } \\
\mathbf{n}=\mathbf{5 0}\end{array}$ & $\begin{array}{c}\text { Sundarbazar } \\
\mathbf{n}=\mathbf{5 0}\end{array}$ & \\
\hline Yes & $21(42.0)$ & $28(56.0)$ & $49(49.0)$ \\
\hline No & $29(58.0)$ & $22(44.0)$ & $51(51.0)$ \\
\hline
\end{tabular}

Table 18: Insect-pests and disease management practiced by respondents.

Figures in the parenthesis indicate percentage

\begin{tabular}{|l|l|l|l|}
\hline \multirow{2}{*}{$\begin{array}{c}\text { Post harvest } \\
\text { technology }\end{array}$} & \multicolumn{1}{|c|}{\begin{tabular}{c} 
Pocket area \\
Rainas \\
\cline { 2 - 3 }$=\mathbf{5 0}$
\end{tabular}} & $\begin{array}{c}\text { Sundarbazar } \\
\mathbf{n = 5 0}\end{array}$ & $\begin{array}{c}\text { Total } \\
\mathbf{n = 1 0 0}\end{array}$ \\
\hline One practice & $15(30.00)$ & $7(14.00)$ & $22(22.0)$ \\
\hline Two practices & $22(44.00)$ & $37(74.00)$ & $59(59.00)$ \\
\hline Three practices & $13(26.00)$ & $6(12.00)$ & $19(19.00)$ \\
\hline Mean & - & - & 33.33 \\
\hline $\begin{array}{l}\text { Standard devia- } \\
\text { tion }\end{array}$ & - & - & 22.27 \\
\hline Range & - & - & $1-3$ practice \\
\hline
\end{tabular}

Table 19: Post harvest technology adopted by the respondents.

Figures in the parenthesis indicate percentage

Productivity of rice in the study area

From the study it was found that, majority of respondents (84 percent) had 2.5-5.0 $\mathrm{mt}$ per hectare productivity of rice followed by 11 percent respondents had less than $2.5 \mathrm{mt}$ per hectare and 14 percent respondents had above $5 \mathrm{mt}$ per hectare of rice productivity. The result indicates that majority of respondents had better productivity of rice. The average rice productivity of the study area was $3.89 \mathrm{mt}$ per hectare whereas district average is $2.07 \mathrm{mt}$ per hectare and national average is $2.89 \mathrm{mt}$ per hectare.

Sources of knowledge used by farmers for rice cultivation

Farmers gained the knowledge of rice cultivation from different sources. The sources of knowledge used by farmers for rice cultivation were classified in to three categories; personal localite, personal cosmopolite, and mass media. Among the different sources of knowledge, the important sources of knowledge used by the farmers for rice cultivation, were neighbors and friends, followed by radio/television, self-experience, JT/JTAs, relatives, village leaders, progressive farmers, printed materials, demonstration, DADO, research farm, cooperatives, agro-vets and scholars. 


\begin{tabular}{|l|c|c|c|}
\hline \multirow{2}{*}{$\begin{array}{c}\text { Productivity } \\
\text { of rice (mt per } \\
\text { hectare) }\end{array}$} & \multicolumn{2}{|c|}{ Pocket area } & \multirow{2}{*}{ Total } \\
\cline { 2 - 3 } & $\begin{array}{c}\text { Rainas } \\
\mathbf{n = 5 0}\end{array}$ & $\begin{array}{c}\text { Sundarbazar } \\
\mathbf{n = 5 0}\end{array}$ & \\
\hline$<2.5$ & $5(10.0)$ & $6(12.0)$ & $11(11.0)$ \\
\hline $2.5-5.0$ & $41(82.0)$ & $41(82.0)$ & $82(84.0)$ \\
\hline$>5.0$ & $4(8.0)$ & $3(6.0)$ & $7(14.0)$ \\
\hline Mean & 3.89 & - & - \\
\hline $\begin{array}{l}\text { Standard } \\
\text { deviation }\end{array}$ & 1.23 & - & - \\
\hline Range & 1.92 & - & - \\
\hline
\end{tabular}

Table 20: Productivity of rice in the study area.

Figures in the parenthesis indicate percentage

\begin{tabular}{|l|c|c|c|}
\hline Sources of information & Score & Index value & Rank \\
\hline Personal Localite \\
\hline Neighbors friends & 107 & 0.35 & I \\
\hline Relatives & 55 & 0.18 & V \\
\hline Village leader & 43 & 0.14 & VI \\
\hline Progressive farmer & 36 & 0.12 & VII \\
\hline Personal Cosmopolite & 83 & 0.27 & IV \\
\hline JT/JTA & 21 & 0.07 & X \\
\hline DADO & 12 & 0.04 & XII \\
\hline Cooperative & 5 & 0.016 & XIV \\
\hline Municipality & 4 & 0.013 & XV \\
\hline School teachers & 90 & 0.30 & II \\
\hline Mass Media & 29 & 0.09 & VIII \\
\hline Radio/ Television & 24 & 0.08 & IX \\
\hline Demonstration & 89 & 0.29 & III \\
\hline Printed material & 15 & 0.05 & XI \\
\hline Self- experience & 6 & 0.02 & XIII \\
\hline Research farm & \multicolumn{5}{|l}{} \\
\hline Agro- vet & & & \\
\hline
\end{tabular}

Table 21: Sources of knowledge used by the respondents.

Note: Score value ranged from 3 to 0 , where; $3=$ most frequent contact, $2=$ frequently contact, $1=$ seldom contact and $0=$ never contact

Level of adoption of improved rice technology

Form the study it was found that, majority of the respondents (74 percent) had high level of adoption followed by moderate level of the respondents (26 percent). This finding indicates that the level of adoption of the respondents was satisfactory.

\begin{tabular}{|l|l|l|}
\hline \multicolumn{1}{|c|}{ Adoption level } & \multicolumn{1}{c|}{ Frequency } & \multicolumn{1}{c|}{ Percentage } \\
\hline Moderate (33-66\%) & 74 & 74 \\
\hline High $(>66 \%)$ & 26 & 26 \\
\hline Total & 100 & - \\
\hline Mean & 74.16 & - \\
\hline Standard deviation & 13.58 & - \\
\hline
\end{tabular}

Table 22: level of adoption of rice technology

Factors affecting adoption of improved rice technology

Multivariate regression analysis was carried out to measure the factors associated with adoption level (dependent variable) under this study. The coefficient of determination R2 is 0.213 indicating there was 21.3 percent of variation in the adoption of rice technology explained by the included explanatory variables. The R2 value of 0.213 indicates that all the selected 8 variables put together contributed for about 21.3 percent variation for the adoption of rice technology. Level of education and extension contact were significant at 0.01 level. Increase in level of education had positive contribution towards technology adoption. The result indicates that the increase frequency of extension contact contributed positively to the adoption of rice. Increased number of extension worker contact encouraged the farmers to cultivate the rice with improved technology.

\begin{tabular}{|l|c|c|c|c|c|}
\hline $\begin{array}{l}\text { Independent } \\
\text { variables }\end{array}$ & $\begin{array}{c}\text { Beta } \\
\text { Coeffi- } \\
\text { cient }\end{array}$ & $\begin{array}{c}\text { Standard } \\
\text { Error }\end{array}$ & $\begin{array}{c}\text { T- } \\
\text { value }\end{array}$ & $\begin{array}{c}\text { Signifi- } \\
\text { cance }\end{array}$ & $\mathbf{R}^{2}$ \\
\hline Age & -.019 & .120 & -.154 & .878 & \\
\hline $\begin{array}{l}\text { Level of } \\
\text { education }\end{array}$ & 3.974 & 1.610 & 2.468 & $0.155^{* *}$ & $\mathbf{0 . 2 1 3}$ \\
\hline Family size & -.516 & .547 & -.934 & .348 & \\
\hline Farm size & -3.896 & 2.330 & -1.672 & .098 & \\
\hline $\begin{array}{l}\text { Annual } \\
\text { income }\end{array}$ & .000 & .000 & .696 & .488 & \\
\hline $\begin{array}{l}\text { Organization- } \\
\text { al member- } \\
\text { ship }\end{array}$ & 2.139 & 3.049 & .702 & .485 & \\
\hline Training & 1.404 & 3.540 & .397 & .639 & \\
\hline $\begin{array}{l}\text { Extension } \\
\text { contact }\end{array}$ & 3.257 & .961 & 3.389 & $.001^{* *}$ & \\
\hline Adjusted R & 0.144 & & & & \\
\hline
\end{tabular}

Table 23: Regression analysis of adoption with socio-economic and other related factors.

** significant at the 0.01 level (2-tailed)

*significant at the 0.05 level (2-tailed) 
Relationship between socio-economic and other factors of adoption

The study shows that level of education (0.007), extension contact (0.002), had positive significant relationship with the level of adoption. Annual income, group membership and training had positive relationship but were non-significant. Similarly, age, family size and farm size had negative releationship but had no any significance towards adoption of technology in rice agribusiness sector.

\begin{tabular}{|l|c|c|c|}
\hline S.N & Factors & r-value & p-value \\
\hline 1 & Age & -0.138 & 0.170 \\
\hline 2 & Level of education & $0.269 * *$ & 0.007 \\
\hline 3 & Family size & -0.119 & 0.239 \\
\hline 4 & Farm size & -0.105 & 0.298 \\
\hline 5 & Annual income & 0.011 & 0.913 \\
\hline 6 & Group membership & 0.139 & 0.167 \\
\hline 7 & Extension contact & $0.300^{* *}$ & 0.002 \\
\hline 8 & Training & 0.097 & 0.339 \\
\hline
\end{tabular}

Table 24: Correlation of adoption with socio-economic and extension related factors.

** significant at the 0.01 level (2-tailed)

*significant at the 0.05 level (2-tailed)

Major constraints faced by farmers on rice cultivation

Various problems were mentioned and assigned scores by the rice growing farmers. Problems of quality seeds, insecticides and pesticides, lack of fertiizers, lack of insect pest and disease management, lack of storage, lack of marketing and price, lack of credits and lack of irrigation were ranked hierarchically by the respondents of the study area of production.

\begin{tabular}{|c|c|c|c|}
\hline S.N. & Constraints & Frequency & Rank \\
\hline & Quality seeds & 81 & I \\
\hline & Insecticides/pesticides & 66 & II \\
\hline & Fertilizer & 65 & III \\
\hline & $\begin{array}{c}\text { Insect-pests and disease } \\
\text { management }\end{array}$ & 54 & IV \\
\hline & Storage & 49 & V \\
\hline & Marketing and Price & 45 & VI \\
\hline & Agricultural loan & 43 & VII \\
\hline & Irrigation & 37 & VIII \\
\hline
\end{tabular}

Table 25: Constraints pertaining to rice production by the farmers.

\section{Conclusion}

Majority of the respondents of study area were male and minority were female. Majority of the respondents were in the middle aged group and economically active population. The study area was dominated by Brahmin community and Hindu religion. The family size was greater than district average and national average. Majority of the respondents of the study area were literate and minority of the respondents were illiterate and having higher education. The literacy rate of the respondents of the study area was greater than district and national literacy rate. The income of the respondents of study area was higher than per capita of Nepal. There was wide variation in annual income among the respondents. The average land holding size of the respondents was 0.68 hectare. Majority of the respondents were affiliated to the farmer's groups and other organizations and they were the members of those organizations and received the membership from them. Majority of the respondents had obtained training related to rice production technology from different organizations ASC (Agriculture Service Centre), DADO (District Agriculture Development Office), RATC (Regional Agriculture Training Centre) etc.

The major cropping pattern of the study area was rice-wheatrice followed by rice-fallow-rice and rice-vegetable-rice. Major sources of knowledge of the farmers were personal localite. Farmers gain more knowledge from their neighbors, friends and relatives. And other sources were JT/JTAs, Radio and Television, printed materials etc. Three-fourth of the respondents under this study had high level of adoption and remaining had moderate level of adoption. This finding indicates that level of rice technology adoption of the respondents in the study area was satisfactory because majority of the farmers had higher level of adoption. The level of education and extension contact showed significant and positive relationship with the level of adoption of recommended cultivation practices of rice. These factors could be promoted and incorporated into the other extension programs to enhance the dissemination and promotion of rice technology.

Training and organizational membership had positive relationship with the level of adoption in rice agribusiness sector. Thus it is necessary to provide training to the farmers who had not obtained and motivate them to become member in the group. The adoption of improved rice technology was largely constrained by lack of quality seed, disease, insect-pest problem, manures and fertilizers, storage marketing and price, agricultural loan and irrigation. 


\section{Bibliography}

1. NRRP. Rice Annual Report. Hardinath, Dhanusha: Nepal Agriculture Research Council (2004).

2. NRRP. Rice research in Nepal, Proceedings of the 24th Summer Crop Worksop. Nepal Agriculture Research Council (NAARC). Hardinath, Dhanusha: Naepal Argriculture Research Council (2004).

3. FAOSTAT. Agriculture Statistical Database. Rome, Italy: Food and Agriculture Organization (2015).

4. CBS. Statistical Pocket Book of Nepal. Singhadurbar, Kathmandu, Nepal: National Planning Commission Secretariat, Government of Nepal (2007).

5. MoAD. "Selected Indicators of Nepalese Agriculture and Production". Singhadurbar, Kathmandu, Nepal: Agri-business Promotion and Statistics Division (2014).

6. ABPSD. Statistical Information in Nepalese Agriculture. Singhadurbar, Kathmandu, Nepal: Agri-business Promotion and Statistics Division (2015).

7. NARC. Annual Report. Khumaltar. Lalitpur, Nepal: National Agriculture Research Council (2012).

8. Gautam P. "Technology Adoption of Agricultural Commodities in Nepal”. Nepalese Journal of Agriculture 6.5 (2013).

9. Kharg GE. "Agricultural Technology Adoption Behaviour of Rural Farmers". International Journal of Extension Education 33.3-4 (2014).

10. Moshe A. An introduction to agricultural extension. Agricultural Development Council (2012): 114.

11. Dongol B. Extension Eduacation. Inakha, Gopal Tole, Kathmandu, Nepal: Prativa Singh Dongol (2004).

12. Upreti R. Factors influencing participation of farmers group activities in the Sunsari distrcit of Nepal. Msc Ag Thesis. Department of Agriculture Extension and Rural Sociology: IAAS, Rampur, Chitwan, Nepal (2003).

13. DADO. Annual Report. District Agriculture Development Office, Lamjung, Nepal (2017).
14. AICC. Agriculture Diary. Singhadurbar, kathmandu, Nepal: Agriculture Information and Communication Centre (2016).

15. DDC. District Profile of lamjung. Lamjung, Nepal: Distrcit Development Committee (2015).

\section{Volume 3 Issue 8 August 2019}

(C) All rights are reserved by $S$ Ghimire and S Parajuli. 